\title{
ACTUALIZATION OF DRINKING CULTURE IN THE ENGLISH-SPEAKING WORLDVIEW
}

Olesia Yehorova, PhD in Philology;

https://orcid.org/0000-0002-3225-5580

Iryna Tretiak, student

Sumy State University,

2, Rymskogo-Korsakova St., Sumy, 40007, Ukraine

E-mail: o.egorova@gf.sumdu.edu.ua; iratretyak123456@i.ua

The article approaches the phenomenon of drinking culture from the standpoints of both social security and linguoculture. It suggests a brief historical overview of European drinking. For a better understanding of how drinking culture is conceptualized and categorized in the English-speaking worldview, the study identifies a system of means that feature the notion of drinking culture in the English language. The objective is gained through modeling a lexico-semantic field which constitutes the units of different parts of speech that correlate with one fragment of reality and have common elements of semantics.

Within the modeled lexico-semantic field "drinking" 10 lexico-semantic groups are identified; main characteristics of this field are designated. Among those are structuredness and systematic character, hierarchical ordering, core-periphery organization, internal distribution into lexico-semantic groups with fuzzy boundaries, the relative independence of the field, the existence of synonymic, antonymic and associative connections between the elements of the field etc.

Keywords: drinking culture, English-speaking worldview, lexico-semantic field, lexicosemantic group.

https://doi.org/10.21272/Ftrk.2018.10(4)-3

Introduction. The interaction between culture and language was paid heed to since long ago. Since then, this interconnection has been generating the interest of researchers from different fields of knowledge. Special attention to this fact was given by the linguists who came to the conclusion that the people's understanding of the world (worldview) is inevitably reflected in language.

Drinking is a sociocultural phenomenon that is rooted in history. In the course of evolution, drinks and beverages became not only an integral part of people's food ration but also a certain cultural element or symbol for various ethnic groups.

Over the centuries, the so-called "drinking culture" has formed in many parts of the world. Drinking culture is a component of the most national cultures of the contemporary world. It covers many aspects that directly or indirectly influence the development of the linguistic worldview of each particular ethnic group.

In many cultures, this phenomenon and reality take on a prominent place and along with any other significant cognitive experience get reflected in language. Studying the features of the drinking culture's representation in languages gives insight into the conceptualization of this phenomenon within a particular linguoculture, the ways of reflecting human mental activity as well as the interrelationship between the culture, language, and speech. For a better understanding of how drinking culture is conceptualized and categorized, it is to identify a system of language means that actualize the concept of drinking in the English language and discourse.

The study of drinking culture has begun relatively recently, in particular by the British and Australian scientists. A set of works on this issue were published by R. Gordon,

(C) Yehorova O., Tretiak I., 2018 
D. Heim, M. Livingston, S. MacAskill, K. Makela, J. Mugavin, A. Pennay, R. Room, M. Savic, etc. [1; 2;3] who approach drinking culture from the standpoint of social security. However, studying the drinking culture from the standpoint of linguoculturalism still remains in the initial stage which determines the relevance of this work.

The objective of the article is to model the lexico-semantic field "drinking" and to analyze the ways of the drinking culture representation in modern English language. In this light, the tasks of the research look as follows:

- to characterize the sociocultural significance of the drinking culture phenomenon;

- to define the term "drinking culture" and to determine its main content;

- to distinguish the basic constituents of the lexico-semantic field "drinking" in the English language and to determine their status;

The subject matter is the drinking culture in the English-speaking worldview.

The specific topic of study is the lexical profiling of the drinking culture in modern English language.

The methods of study are descriptive, componential, semantic, and comparative historical analysis.

Results of the research. In the most general sense, drinking is understood as the process of absorbing the liquid through the mouth. From the position of the language system in the context of the English-speaking worldview, the meaning of the noun "drinking" and the corresponding verb "to drink" denotatively narrow to the consumption of alcoholic beverages.

To drink:

1) to partake of alcoholic beverages [4];

2) to drink alcohol [5];

3) to drink alcohol, especially when it is done regularly [6];

4) to consume alcohol, esp to excess [7]. Accordingly, within this work, the drinking culture is considered exclusively in the context of alcohol consumption.

Alcohol consumption is a fundamental part of the culture of almost every nation. People began to produce alcoholic drinks 8,000 years B.C., after the development of agriculture and the establishment of settled communities. Pure alcohol was distilled by the Arabs already in the VI-VII centuries. Traditionally, the name alcohol is treated as a derivation from Arabic "al-kuhul" where kohl means "the fine metallic powder used to darken the eyelids", from kahala "to stain, paint" [8]. However, Rachel Hajar, MD, believes that the word alcohol was derived from Arabic but from another word: al-kol (al-ghol.): "The old Arabic dictionaries state that: Al-Kol (Al-ghol): 1. A genie or spirit that takes varied forms and shapes (a supernatural creature in Arab mythology). 2. Any drug or substance that takes away the mind or covers it. Obviously, the last statement fits well with alcohol - it does take away the mind" [9, c. 343].

In a broad sense, the drinking culture can be defined as a set of customs and traditions of consumption of alcoholic beverages, inherent in a particular ethnic culture. Some people consider alcohol as an important and sacred cultural artifact, the others perceive it as something insignificant or even devastating. Some cultures impose the abstinence from drinking, the others admit it only as part of religious ceremonies [10, p. 248].

The scientific literature on alcohol consumption extensively uses the term "drinking culture", but there is no unity in describing the meaning of this concept. A team of Australian sociologists sees "drinking culture" as "the rules and patterns of drinking inherent in a particular social group of people" [1, p. 8].

Drinking culture undergoes constant changes and modifications. The ancient Greeks and Romans were among the first who clearly expressed their position towards alcohol and outlined the advantages and disadvantages of its consumption.

Alcohol, primarily wine, played a key role in both Greek and Roman cultures. Wine was ubiquitous. The Greeks and Romans presented it as a gift to their deities, used it as a currency to pay for the rare and precious goods from distant countries, drank it on holidays, during the rituals, as the medicines, and just in order to quench their thirst. In some Greek 
cities, such as Athens, wine consumption was a civic duty [11, p. 21]. In other words, wine was a constitutive element not only of the Greek and Roman cultures but it was also an iconic characteristic of daily life. This special status of intoxicating beverages is reflected in the old popular saying "In vino veritas" (In wine, there is the truth).

The Greek and Roman drinking cultures gave rise to the establishment of drinking cultures in other regions of Europe. One of the first territories influenced by the Roman drinking culture were the British Isles whose romanization began in 43 B.C. with the arrival of the Roman emperor Tiberius Claudius. By 96 B.C., most of England and Wales had been annexed to the Roman Empire. By that time, Britain was inhabited by the Celtic tribes who had been consuming beer only. The Romans shared the winemaking technology with the Celts, so in the course of romanization, speech and discourse the Celts also began to worship Bacchus (Dionysus), the god of viticulture and winemaking [11, p. 51].

The significance of drinking phenomenon in Great Britain is evidenced by a variety of cultural elements reflected in the architecture, literature, fine arts, music, and folklore. For example, there is the Scottish Whiskey Museum in Edinburgh that holds the largest collection of bottles in the world (about 3,800 pieces). Moreover, on July, 27th the whole Britain celebrates the national Scotch Whiskey Day. However, the best evidence of the significance of any phenomenon in culture is the folk wisdom since it is being transmitted from generation to generation and keeps the traces of different historical periods. Numerous proverbs and sayings actualize positive and negative attitude of the British folk to alcohol. E.g. "Drunken days have all their tomorrows," "Drunkenness reveals what soberness conceals", "Whiskey make a rabbit hug lion", etc.

Drinking culture is considered a part of the general culture of mankind and within each particular ethnoculture, it receives specific forms of verbalization.

The thoughts about the close relations between the internal structure of a language and the culture began to appear in the XVIII century. The words are marked by their structural, semantic, grammatical, and pragmatic filling. Their lexico-grammatical variability is unique. Words, like icebergs, conceal their meaning which is revealed in modes of language, speech, and discourse [12, p. 28].

Linguistic worldview analysis primarily envisages studying the lexical representation of the most linguoculturally important fragments of cognitive experience.

The Ukrainian linguist O. D. Ohui in his article on the components of the linguistic worldview notes that it manifests itself as a customized application field of the lexical system. As an aggregation of lexemes, this system is marked by certain paradigmatic, syntagmatic, epidygmatic, and pragmatics features, and serves to reflect the ideological, cognitive, and transformative activity of the individual in the language community [13, p. 16]. Thus, we believe that a lexico-semantic field (LSF) acts as one of the most effective tools for systematizing and analyzing the components of the linguistic worldview since it is the largest paradigm that combines the words of different parts of the speech which feature the same fragment of reality and have common elements of semantics.

In linguistics, the idea of studying the lexical system by grouping its elements by semantic (notional) fields is connected with the name of J. Trier [14] who was primarily interested in what could be taken as the basis for the selection of a certain set of words from the general vocabulary. Such criterion, as he saw it, could be the common elements of meaning shared by the constituents of word groups. The fields, according to J. Trier, are divided into lexical and notional (conceptual): notional (conceptual) field is a wide system of interrelated notions (concepts) organized around the central notion (concept), whereas the lexical field is formed by any single word and its "family of words" [14, p. 49-53]. Thus, a certain lexical field covers only some separate part of the notional field; the other part is covered by another lexical field, i.e. one and the same word can enter several different fields, and the words within the lexico-semantic field should be considered both from the aspects of syntagmatics and paradigmatics.

Modern research works in linguistics suggest different definitions of the lexicosemantic field (LSF). In particular, it is defined as a set of language (mainly lexical) units 
with common content that reflects the notional, objective, or functional similarity of the denotated phenomena [15, p. 84]. Any LSF features:

1) the presence of semantic correlations among the field constituents;

2) the systemic nature of relations in the field;

3 ) the presence of microfields within the field;

4) the hierarchical organization of the field;

5) the core-peripheral structure of the field;

6) the fuzzy boundaries of the core, periphery, and microfields;

7) the interdependence of lexical units within the field;

8) the relative autonomy of the field;

9) the interrelationship between the semantic fields within the entire lexical system;

10) the partial overlaying of the fields and the formation of gradual transition zones [16, p. 105-113; 17, p. 99]. Such set of properties characterizes LSF as a complex mechanism of organizing language units which intercorrelate both within the field and beyond with the components of other fields.

LSF consists of lexico-semantic groups (LSG) formed by the language units of one part of speech with shared integral semes [18, p. 87]. The immediate constituents of the lexicosemantic field are the language units located in its center or in the periphery. The central zone accumulates lexemes that most vividly refer to the denotatum, are characterized by generalized semantics, stylistic neutrality, and highest frequency of use in speech. The rest units with a lesser strength of semantic connections between the semes and those that feature narrower (specific) meanings spread about the periphery and thus, form intersection zones with other lexico-semantic fields.

Since any human activity is reflected in language, we assume that in the Englishspeaking worldview, drinking culture forms a certain language field whose elements can be systematized and structurized and their semantic interconnection defined. For this, within the study of the "drinking culture" concept, we attempt at modeling the LSF "drinking" and distinguishing its constituents and semes which unite the LSGs within this field.

The verb to drink comes from the Old English drincan which means "to swallow water or liquid" as well as "to absorb". The meaning "to drink alcohol" the verb to drink developed in the middle of XV century [19]. The definitions of the word "drinking" in various dictionaries $[5 ; 6 ; 8 ; 20 ; 21 ;]$ explicate the generalized meaning of consuming alcohol ("the action or habit of consuming alcohol").

The noun drinking is derived from the verb to drink two core semes in its semic structure:

1) to take liquid into the body through the mouth (e.g. He drank his cup of tea);

2) to drink alcohol (e.g. They spent the evening drinking in a bar) [6].

A similar verbal nature is explicated by the noun drink which in modern English language is used for denoting:

1) an amount of liquid that you drink, or the act of drinking something (e.g. Have a drink of water);

2) any liquid that you can drink (e.g. What's your favourite drink?);

3) an alcoholic drink (e.g. He'd obviously had a few drinks);

4) the habit of drinking too much alcohol, in a way that is very bad for your health (e.g. After her retirement from the stage she took to drink) [21]. The definitional analysis shows that the verb to drink and its derivatives, which form the core of the lexico-semantic field "drinking", have a shared seme "the consumption of alcoholic beverages".

Within this study, we applied the continuous sampling method and selected the meanings of more than 200 lexemes multifacetedly actualizing drinking culture. The semantic analysis of them allowed us to split these units into 10 main LSGs which constitute the LSF "drinking". These include:

1) verbal units featuring the act of alcohol consumption [ACTION]:

- root verbs: to drink, to tipple, to indulge, to booze, to nip, to tope, to carouse $(A m E)$; 
- word groups: to have a drink, to have a pint, to go on a bender, to have a skinful, to get drunk, to take a pull;

- phrasal verbs: to belt down, to drink down, to knock back, to lap up, to lick off/up, to tank up, to sip at, to put forward, to swill down, to lager up, to liquor up;

2) units that describe the mode [HOW] of alcohol consumption: regular, moderate, social, responsible, binging, heavy;

3) units that feature the duration of alcohol consumption [HOW LONG]: bout, spree, binge, jag, dipsomania, alcoholism, (alcoholic) abuse / addiction, hard drinking;

4) units that denote the person who consumes / doesn't consume alcohol [WHO] or their lifestyle:

- in general: drinker, alcohol consumer,

- on a regular basis: drunkard, sot, alcoholic, drinker, dipsomaniac, tippler (AmE), wino (AmE), pisshead, barfly (AmE), boozer, lush, winebibber, soak, stew, rummy;

- never: sobriety, teetotalism, abstemiousness, abstention, abstinence, nonindulgence, temperance teetotaller, (total) abstainer, nondrinker, water-drinker, dry;

5) units that denote alcoholic beverages [WHAT] and their characteristics [WHAT KIND]:

- general names: alcohol, drink, intoxicant, booze, hooch, firewater (AmE), bottle, brew, beverage, spirits, juice (AmE), sauce (AmE);

- general qualities: strong, heady, stiff, light, weak, full-bodied, iced, on the rocks, neat, straight (up),

- kinds of alcoholic beverages: wine, beer, gin, ale, whiskey, brandy, vodka, cider, tequila, liquor,

- nouns that denote the raw material for alcohol production: hop, malt, grape, barley;

units that denote the volume of alcohol consumed or served [HOW MUCH]:

- names of containers: mug, tankard, pint, jar, pitcher, bottle, stein, toby, cup, tumbler, glass, beaker, goblet;

- volume characteristics: long, short, tall.

7) units that denote the places of usual alcohol consumption [WHERE]: pub, bar, tavern, clubhouse, bistro, boozer, restaurant, inn, joint, lounge, saloon, taproom, hostelry;

8) nouns that denote the occasions for alcohol consumption [WHY]: party, banquet, bash, beanfeast, feast, blowout, booze-up, celebration, debauch;

9) units that refer to the degree of alcohol intoxication [OUTCOME]:

- in general: drunkenness, intoxication, inebriation / inebriety, insobriety, intemperance, sottishness, bibulousness, crapulence, crapulousness, tipsiness, ebriety dipsomania, alcoholism, ebriosity, hangover; drunken, inebriate(d), pissed, screwed (AmE), pixilated, tipsy, boozy, tanked, sloshed, woozy, foxed (AmE), jaggy, soused (AmE), intoxicated, besotted, groggy, pickled, squiffy;

- figuratively: drunk as fire, drunk as rosin, drunk as a lord, drunk as a fiddler, drunk as a fish, dead drunk, drunk as a cobbler, drunk as a skunk, roaring drunk, sober as a Judge, three sheets to the wind, to be bevvied up, pissed as a newt;

10) set expressions and word phrases used as a toast during the consumption of alcoholic beverages: Bottoms up! Prosit!, To your (very good) health!, Cheers!, Here's to!, Skol!

The biggest in number LSGs are those that denote the process of alcohol consumption, designate the person and object of consumption as well as its outcomes. Each of these groups features lexical units derived from the word drink that gives more reasons to attribute this lexeme and its derivatives to the core of the LSF "drinking". Alongside, the center of the field is formed by the lexemes that actualize secondary attributes of the "drinking act" (its locale, its mode, its duration, etc.) but are not derived from the lexeme drink. Thus, in particular, the elements of the center of LSF "drinking" are such units as pub, bar, intoxication, alcohol, (alcoholic) abuse / addiction, social / heavy / binge drinking, insobriety, tipsy, booze, etc.

The periphery of the field is formed by the lexical units which in their meaning are the most distant from the core and are the least frequently used in speech in comparison to the 
constituents of core and the center zones. The periphery hosts such units as to carouse, to tope, cup, tumbler, goblet, jaggy, sauced, foxed, drunk as fire, drunk as rosin, drunk as a lord, Bottoms up! Prosit!, etc.

Undeniable is the fact that LSGs rely on certain semantic relationships, in particular, synonymic and antonymic ones. This is confirmed by a number of lexemes that refer to the same concept and by the antonymic pairs that equally describe the concept. The best example of such dichotomy is the LSG for denoting the person who consumes or abstains from alcohol.

LSF "drinking" features not only synonymic and antonymic relations between its constituents but also on associative ones because its components are the lexemes that form associative chains. Their elements denote different objects that can be used in different contexts but that correlate with the same notion, in our case, with alcohol. For example, mug, tankard, pint, jar, pitcher, bottle, etc.

Conclusions. Drinking culture is considered as a part of a nationwide culture: it covers the system of values, cultural norms, symbols and priorities which are related to the alcohol consumption and are reflected both in culture and language. The concept of drinking culture is complex and multifaceted; it embraces a large number of diverse aspects and it is studied within the framework of social security and linguoculture.

On the basis of modeling the lexico-semantic field "drinking", which encompasses sets of words with shared semantics that belong to different parts of speech, we distinguished 10 lexico-semantic groups, each of them referring to and describing different aspects of alcohol consumption. The constituents of the LSGs are in synonymic, antonymic, and associative relationships with each other and spread about the core, central, and periphery zones of the field, depending on the level of semantics prototypicality that they feature. Lexeme drink and its derivatives, belonging to the core zone, possess the most prototypical semantics and are the most frequently used in speech; the elements of the central zone strongly and directly refer to the denotatum or its main features/aspects, and the periphery zone form language units, most distant from the core in their semantics.

The further study of the problem is seen is setting up a metaphoric profile of drinking culture in modern English language.

\section{АКТУАЛІЗАЦІЯ КУЛЬТУРИ ПИТТЯ В АНГЛОМОВНІЙ КАРТИНІ СВІТУ}

О. І. Сгорова, канд. філол. наук,

https://orcid.org/0000-0002-3225-5580

I. В. Третяк, студентка

Сумський державний університет,

вул. Римського-Коросакова, 2, м. Суми, 40007, Украӥна

E-mail: o.egorova@gf.sumdu.edu.ua; iratretyak123456@i.ua

У статті розглядається культура пиття як з позииії соиіальної безпеки, так $i$ з позииіі лінгвокультурологї, здійснюється короткий екскурс в історію європейської культури пиття. Зокрема увага акиентується на визначенні поняття культури пиття, а також на детерміначії сочіокультурної значущості иььго феномену. У роботі аргументується актуальність культури пиття в різних етносах, зокрема в британській культурі. Актуальність дослідження культури пиття в англомовній картині світу зумовлена недостатньою теоретичною та практичною розробкою иього питання з позииій лінгвокультурологіі.

У ході роботи було встановлено, що будь-який культурний досвід людини знаходить своє відображення в мові, а найкращим засобом упорядкування, аналізу та систематизування лексичних одиниць, якими представлена мовна картина світу, є лексико-семантичне поле. Окреслюються основні теоретичні засади його організації та моделювання, виокремлюються спільні властивості, притаманні будь-якому лексико-семантичному полю.

Для кращого розуміння концептуалізачії та категоризачії культури пиття ідентифікується система мовних засобів актуалізації поняття "drinking” в англомовній картині світу, зокрема моделюється та аналізується лексико-семантичне поле “drinking”. Конституенти иъього поля є одинииями різного частиномовного подання, які співвідносяться з одним фрагментом дійсності й мають спільні елементи семантики

Моделювання та аналіз лексико-семантичного поля “drinking” показує, щчо воно представлене 10 основними лексико-семантичними групами, кожна з яких складається зі слів різних частин мови на 
позначення різних явищ, які максимально фіксуються в межах культури пиття. Визначаються також основні характеристики цього поля, зокрема, структурованість та систематизованість, ієрархічна будова, відсутність чітких меж між його конституентами, ядерно-периферійна організація, наявність мікрополів та лексико-семантичних груп, відносна самостійність поля, взаємообумовленість лексем, що входять в це поле, нечітка розмежованість між ядерною та периферійною зонами, а також наявність синонімічних, антонімічних і асоціативних зв'язків між його елементами.

Ключові слова: культура пиття, англомовна картина світу, лексико-семантичне поле, лексикосемантична група.

\section{АКТУАЛИЗАЦИЯ КУЛЬТУРЫ ПИТИЯ В АНГЛОЯЗЫЧНОЙ КАРТИНЕ МИРА}

О. И. Егорова, канд. филол. наук,

https://orcid.org/0000-0002-3225-5580

И. В. Третяк, студентка

Сумский государственный университет,

ул. Римского-Корсакова, 2, г. Сумы, 40007, Украина

E-mail: o.egorova@gf.sumdu.edu.ua; iratretyak123456@i.ua

В статье рассматривается культура пития как с позиции соџиальной безопасности, так и с позиции лингвокультурологии, осуществляется краткий экскурс в историю европейской культуры пития. Для лучшего понимания конщептуализации и категоризации культуры пития идентифицируется система языковых средств актуализации понятия "drinking" в англоязычной картине мира, в частности моделируется и анализируется лексико-семантическое поле "drinking". Конституенты этого поля являются единицами разных частей речи, которые соотносятся с одним фрагментом действительности и имеют общие элементы семантики.

Моделирование и анализ лексико-семантического поля "drinking" показывает, что оно представлено 10 основными лексико-семантическими группами, каждая из которых состоит из слов разных частей речи для обозначения различных явлений, которые максимально фиксируются в пределах культуры пития. $B$ ходе исследования определяется, что полевая организаџия характеризируется наличием синонимических, антонимических и ассочиативных связей.

ключевые слова: культура пития, англоязычная картина мира, лексико-семантическое поле, лексикосемантическая группа.

\section{REFERENCES}

1. Savic M., Room R., Mugavin J., Pennay A., Livingston M. Defining “drinking culture": A critical review of its meaning and connotation in social research on alcohol problems. Drugs: Education, Prevention and Policy, 2016. 14 p.

2. Room R., Makela K. Typologies of the cultural position of drinking. Journal of Studies on Alcohol, 2000. № 61(3). 475-483 p.

3. Gordon R., Heim D., MacAskill S. Rethinking drinking cultures: A review of drinking cultures and a reconstructed dimensional approach. European Journal. 2012. № 126(1). Public Health, 2012. 3-11 p.

4. Merriam-Webster Dictionary. Merriam-Webster, Incorporated, 2018. - Access mode : https://www.merriamwebster.com/. - (8.11.18)

5. Cambridge Dictionary (2018). Cambridge University Press, 2018. - Access mode : https://dictionary.cambridge.org/. (4.11.18).

6. Oxford Learner's Dictionaries (2018). Oxford University Press, 2018. - Access mode : https://www.oxfordlearnersdictionaries.com/. (15.11.18).

7. Collins Dictionary (2018). Collins, 2018. - Access mode : https://www.collinsdictionary.com/. (21.10.18).

8. Online Etymology Dictionary / ed. By Douglas Harper, 2001-2018. - Access mode : https://www.etymonline.com/word/alcohol. (11.12.18)

9. Hajar R. Alcohol: friend or foe? a historical perspective. Heart Views. 2000. Vol. 1, № 9. September November 2000. 341-344 p.

10. Amodeo M., Jones L. K. Viewing alcohol and other drug use cross-culturally: a cultural framework for clinical practice. Families in Society: The Journal of Contemporary Human Services. 1997. № 78(3). 240$254 \mathrm{p}$.

11. Gately I. A Cultural History of Alcohol . New York, NY: Gotham Books, 2008. 498 p.

12. Shvachko S. A., Kobyakova I. K., Kobyakov A. N. The linguistic world-image: the modus of quantitative vocabulary. Yearbook of Eastern European Studies. 2014. No. 4. 27-43 p. Wroclaw: Russian-Polish Institute.

13. Ohui O D. Linguistic and conceptual world-image: onomasiological problem, semasiological approach, and a holistic perspective. Foreign philology. 2012. Vol. 117. 2012. 35 p.

14. Trier J. Der deutsche Wortschatz im Sinnbezirke des Verstandes. Die Geschichte eines sprachlichen Feldes. 2. Aufl. Heidelberg, 1973. $201 \mathrm{~S}$.

15. Ufimtseva A. A. The lexical meaning. The principle of semasiological description of vocabulary. Moscow : Editorial URSS, 2002. 240 p.

16. Vasiliev L. M. The theory of semantic fields. The linguistic issues. Moscow : Nauka, 1971. № 5. 105-113 p.

17. Kobozieva I. M. The linguistic semantics : the study guide. - M.: Editorial URSS, 2000. $352 \mathrm{c}$. 
18. Zinovieva E. I. The main problems of vocabulary description in the aspect of Russian as a foreign language. 2nd ed., SPb. : Philol. Fac. SPbGU, 2005. 88 p.

19. Online Etymology Dictionary / ed. By Douglas Harper, 2001-2018. - Access mode : https://www.etymonline.com/word/culture. (4.11.18).

20. English Oxford Living Dictionaries. Oxford University Press, 2018. - Access mode https://en.oxforddictionaries.com/. (4.11.18)

21. Longman Dictionary of Contemporary English. Access mode : https://www.ldoceonline.com/. - (8.11.18).

\section{СПИСОК ВИКОРИСТАНИХ ДЖЕРЕЛ}

1. Savic M. Defining "drinking culture": A critical review of its meaning and connotation in social research on alcohol problems / M. Savic, R. Room, J. Mugavin, A. Pennay, M. Livingston. - Drugs: Education, Prevention and Policy, 2016. -14 p.

2. Room R. Typologies of the cultural position of drinking. / R. Room, K. Makela. - Journal of Studies on Alcohol, 2000. - № 61(3). - 475-483 p.

3. Gordon R. Rethinking drinking cultures: A review of drinking cultures and a reconstructed dimensional approach / R. Gordon, D. Heim, S. MacAskill. - European Journal. - № 126(1). - Public Health, 2012. - 3$11 \mathrm{p}$.

4. Merriam-Webster Dictionary [Electronic resource] / Merriam-Webster, Incorporated, 2018. - Access mode : https://www.merriam-webster.com/. - (8.11.18).

5. Cambridge Dictionary [Electronic resource] / Cambridge University Press, 2018. - Access mode : https://dictionary.cambridge.org/. - (4.11.18).

6. Oxford Learner's Dictionaries [Electronic resource] / Oxford University Press, 2018. - Access mode https://www.oxfordlearnersdictionaries.com/. - (15.11.18).

7. Collins Dictionary [Electronic resource] / Collins, 2018. - Access mode : https://www.collinsdictionary.com/ $-(21.10 .18)$.

8. Online Etymology Dictionary [Electronic resource] / ed. By Douglas Harper, 2001-2018. - Access mode : https://www.etymonline.com/word/alcohol. - (11.12.18)

9. Hajar R. Alcohol: friend or foe? a historical perspective / Reachel Hajar. - Heart Views vol. 1. - № 9. September - November 2000. - 341-344 p.

10. Amodeo M. Viewing alcohol and other drug use cross-culturally: a cultural framework for clinical practice / M. Amodeo, L. K. Jones. - Families in Society: The Journal of Contemporary Human Services. - № 78(3). 1997. $-240-254 \mathrm{p}$.

11. Gately I. A Cultural History of Alcohol / I. A. Gately. - New York, NY: Gotham Books, 2008. - 498 p.

12. Швачко С. А. Языковая картина мира: модус квантитативной лексики / С. А. Швачко, И. К. Кобякова, A. Н. Кобяков // Yearbook of Eastern European Studies. - No. 4. - Wroclaw: Russian-Polish Institute, 2014. $-27-43 \mathrm{p}$.

13. Огуй О Д. Мовна та концептуальна картини світу: ономасіологічна проблема, семасіологічний підхід та голістична перспектива / О. Д. Огуй - Іноземна філологія. Український науковий збірник Вип. 117. - 2012. - 35 c.

14. Trier J. Der deutsche Wortschatz im Sinnbezirke des Verstandes. Die Geschichte eines sprachlichen Feldes / 2. Aufl. - Heidelberg, 1973. - 201 S.

15. Уфимцева А. А. Лексическое значение. Принцип семиологического описания лексики / А. А. Уфимцева. - М. : Эдиториал УРСС, 2002. - 240 c.

16. Васильев Л. М. Теория семантических полей / Л. М. Васильев // Вопросы языкознания. - М. : Наука 1971. - № 5. - 105-113 c.

17. Кобозева И. М. Лингвистическая семантика : учебное пособие / И. М. Кобозева. - М.: Эдиториал УРСС, 2000. - $352 \mathrm{c}$.

18. Зиновьева Е. И. Основные проблемы описания лексики в аспекте русского языка как иностранного / 2-е изд., доп. СПб. : Филол. фак-т СПбГУ, 2005. - 88 с.

19. Online Etymology Dictionary [Electronic resource] / ed. By Douglas Harper, 2001-2018. - Access mode : https://www.etymonline.com/word/culture. - (4.11.18).

20. English Oxford Living Dictionaries [Electronic resource] / Oxford University Press, 2018. - Access mode : https://en.oxforddictionaries.com/.- (4.11.18).

21. Longman Dictionary of Contemporary English [Electronic resource] / Access mode https://www.ldoceonline.com/. - (8.11.18).

Received: 11 Desember, 2018 